\title{
INDEX OF BOOKS REVIEWED
}

ACOSTA-HUGHES (B.), LEHNUS (L.) and STEPHENS (S.) Eds. Brill's Companion to Callimachus (C. Meliadò) 191

ALWIS (A.P.) Celibate Marriages in Late Antique and Byzantine Hagiography: the Lives of Saints Julian and Basilissa, Andronikos and Athanasia, and Galaktion and Episteme (R. Morris) 308

AMANDRY (P.) and HANSEN (E.) Le Temple d'Apollon du IVe siècle (M. Scott) 272

AMATO (E.) $E d$. Rose di Gaza. Gli scritti retorico-sofistici e le Epistole di Procopio di Gaza (F.K. Haarer) 304

ASTON (E.) Mixanthrôpoi: Animal-Human Hybrid Deities in Greek Religion (J. Kindt) 211

BADOUD (N.) $E d$. Philologos Dionysios: Mélanges offerts au professeur Denis Knoepfler (A. Kühr) 229

BAIRD (J.A.) and TAYLOR (C). Eds. Ancient Graffiti in Context (V.L. Campbell) 277

BAKOGIANNI (A.) Electra Ancient and Modern: Aspects of the Reception of the Tragic Heroine (G. Van Steen) 313

BARDANI (V.N.) and TRACY (S.V.) Eds. Fasc. 5 , Leges et decreta annorum 229/8-168/7 (P.J. Rhodes) 234

BARONOWSKI (D.) Polybius and Roman Imperialism (L.M. Yarrow) 251

BELlelli (V.) $E d$. La Ceramica a Figure Nere di Tipo Attico Prodotta in Italia, I and II (B.A. Sparkes) 265

BERGES (S.) Plato on Virtue and the Law (S.S. Meyer) 288

BILES (Z.P.) Aristophanes and the Poetics of Competition (E.T.E. Barker) 179

BODIOU (L.), GHERCHANOC (F.), HUET (V.) and MEHL (V.) Eds. Parures et artifices: le corps exposé dans l'Antiquité (J. Masseglia) 279

BOMMAS (M.) Ed. Cultural Memory and Identity in Ancient Societies (J.L. Shear) 223

BRISART (T.) Un art citoyen. Recherches sur l'orientalisation des artisanats en Grèce proto-archaïque (A. Rabinowitz) 262

BURASELIS (K.) and MEIDANI (K.) Eds.

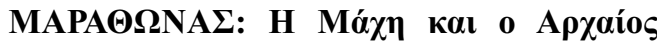
$\Delta$ ýs / Marathon: the Battle and the Ancient Deme (L. Mitchell) 206

CACIAGLI (S.) Poeti e società: comunicazione poetica e formazioni sociali nella Lesbo del
VII /VI secolo a.C. (T.A. Hadjimichael) 162

CARNEY (E.) and OGDEN (D.), Eds. Philip II and Alexander the Great: Father and Son, Lives and Afterlives (E. Koulakiotis) 244

CAWKWELL (G.) Cyrene to Chaeronea: Selected Essays on Ancient Greek History (J. Crowley) 240

CLINE (E.H.) $E d$. The Oxford Handbook of the Bronze Age Aegean (M. Haysom) 256

COOPER (J.M.) Pursuits of Wisdom: Six Ways of Life in Ancient Philosophy from Socrates to Plotinus (M. Schofield) 302

CURTIS (P.) Stesichoros' Geryoneis (T.R.P. Coward) 163

CYRINO (M.S.) Aphrodite (C. Papadopoulou) 220

D'ANGOUR (A.) The Greeks and the New: Novelty in Ancient Greek Imagination and Experience (J. Ober) 184

DANA (M.) Culture et mobilité dans le PontEuxin: approche régionale de la vie culturelle des cités grecques (N. Gourova) 201

DANFORTH (L.) and VAN BOESCHOTEN (R.) Children of the Greek Civil War. Refugees and the Politics of Memory (P. Voglis) 311

DE STEFANI (C.) Paulus Silentiarius, Descriptio Sanctae Sophiae, Descriptio Ambonis (M. Whitby) 305

DIGNAS (B.) and SMITH (R.R.R.) $E d s$. Historical and Religious Memory in the Ancient World (J. Grethlein) 222

DOWDEN (K.) and LIVINGSTONE (N.) Eds. A Companion to Greek Mythology (J. Pratt) 212

EIDENEIER (H.) Äsop - Der Frühneugriechische Roman: Einführung, Übersetzung, Kommentar. Kritische Ausgabe (G.A. Karla) 312

ENGEN (D.T.) Honor and Profit: Athenian Trade Policy and the Economy and Society of Greece, 415-307 B.C.E. (E.M.A. Bissa) 204

ESSLER (H.) Glückselig und unsterblich: Epikureische Theologie bei Cicero und Philodem: Mit einer Edition von PHerc. 152/157, Kol. 8-10 (W.B. Henry) 297

FAIN (G.L.) Ancient Greek Epigrams: Major Poets in Verse Translation (A. Petrovic) 194

FALCON (A.) Aristotelianism in the First Century BCE: Xenarchus of Seleucia (T.L. Gergel) 296 
FARAONE (C.A.) and NAIDEN (F.S.) $E d s$. Greek and Roman Animal Sacrifice: Ancient Victims, Modern Observers (M.-Z. Petropoulou) 217

FEYEL (C.), FOURNIER (J.), GRASLINTHOMÉ (L.) and KIRBIHLER (F.) $E d s$. Communautés locales et pouvoir central dans l'Orient hellénistique et romain (F. Marchand) 248

FINGLASS (P.J.) Ed. Sophocles. Ajax: Edited with Introduction, Translation, and Commentary (M. Catrambone) 169

FISHER (N.R.E.) and VAN WEES (H.) $E d s$. Competition in the Ancient World (B. Keim) 232

FLETCHER (J.) Performing Oaths in Classical Greek Drama (A.L. Allan) 176

FORD (A.L.) Aristotle as Poet: the Song for Hermias and its Contexts (K. Mantzouranis) 189

FOXHALL (L.), GEHRKE (H.J.) and LURAGHI (N.) Eds. Intentional History: Spinning Time in Ancient Greece (R. Harman) 225

FROMENTIN (V.), GOTTELAND (S.) and PAYEN (P.) Eds. Ombres de Thucydide: la réception de l'historien depuis l'Antiquité jusqu'au début du XXe siècle. Actes des colloques de Bordeaux, les 16-17 mars 2007, de Bordeaux, les 30-31 mai 2008 et de Toulouse, les 23-25 octobre 2008 (L. Pitcher) 316

GAUSS (W.) and KIRIATZI (E.) with contributions by M. Georgakopoulou, A. Pentedeka, B. Lis, I.K. Whitbread and Y. Iliopoulos Pottery Production and Supply at Bronze Age Kolonna, Aegina. An Integrated Archaeological and Scientific Study of a Ceramic Landscape (A.-L. Schallin) 255

GILDENHARD (I.) and REVERMANN (M.) $E d s$. Beyond the Fifth Century. Interactions with Greek Tragedy from the Fourth Century BCE to the Middle Ages (L. Prauscello) 315

GILLESPIE (S.) English Translation and Classical Reception. Towards a New Literary History (A. Lianeri) 317

GLAZEBROOK (A.) and HENRY (M.M.) Eds. Greek Prostitutes in the Ancient Mediterranean: 800 BCE - 200 CE (S.L. Budin) 221

GOFF (B.) and SIMPSON (M.) Eds. Thinking the Olympics: the Classical Tradition and the Modern Games (E. Stefanou) 320

GOLDHILL (S.) Victorian Culture and
Classical Antiquity: Art, Opera, Fiction, and the Proclamation of Modernity (C. Edwards) 322

GRAHAM (D.W.) The Texts of Early Greek Philosophy. The Complete Fragments and Selected Testimonies of the Major Presocratics (S. Trepanier) 282

GRAJETZKI (W.) Greeks and Parthians in Mesopotamia and Beyond, 331 BC - 224 AD (L. Gregoratti) 246

GRANDJEAN (Y.) with M. Wurch-Kozelj and T. Kozelj Le rempart de Thasos (S. Mueth) 267 GRANINGER (D.) Cult and Koinon in Hellenistic Thessaly (M. Mili) 245

GRAY (V.J.) Xenophon's Mirror of Princes: Reading the Reflections (L. Mitchell) 226

HALL (E.), ALSTON (R.) and MCCONELL (J.) $E d s$. Ancient Slavery and Abolition. From Hobbes to Hollywood (B. Montoya Rubio) 318

HALLIWELL (S). Between Ecstasy and Truth: Interpretations of Greek Poetics from Homer to Longinus (H.H. Koning) 186

HAYSOM (M.) and WALLENSTEN (J.), Eds. Current Approaches to Religion in Ancient Greece: Papers Presented at a Symposium at the Swedish Institute at Athens 17-19 April 2008 (S. Hitch) 213

HOLLMANN (A.) The Master of Signs: Signs and the Interpretation of Signs in Herodotus' Histories (I. Paintin) 167

HOLMES (B.) Gender: Antiquity and its Legacies (A. Wardrop) 321

HOWLAND (J.) Plato and the Talmud (M.J. Reddoch) 289

HUMBLE (N.) Ed. Plutarch's Lives: Parallelism and Purpose (A.G. Nikolaidis) 196

IRELAND (S.) Menander: the Shield and the Arbitration (A.K. Petrides) 188

JACOBSEN (J.K.) and HANDBERG (S.) Excavation on the Timpone della Motta: Francavilla Marittima (1992-2004). 1. The Greek Pottery (J.K. Papadopoulos) 263

JUNKER (K.) Interpreting the Images of Greek Myths: an Introduction (R. Buxton) 270

KeCHAGiA (E.) Plutarch Against Colotes. A Lesson in History of Philosophy (G. Roskam) 293

KING (R.A.H.) and SCHILLING (D.) Eds. How Should One Live? Comparing Ethics in Ancient China and Greco-Roman Antiquity (J.J. Zhao) 300

KNAPPETT (C.) An Archaeology of Interaction: Network Perspectives on 
Material Culture and Society (B. Legarra Herrero) 258

KREMMYDAS (C.) A Commentary on Demosthenes Against Leptines (K. Kapparis) 186

KUTASH (E.) Ten Gifts of the Demiurge: Proclus on Plato's Timaeus (R. Lamberton) 298

KYRIAKOU (P.) The Past in Aeschylus and Sophocles (L. van Essen-Fishman) 170

LAMBERT (S.D.) $E d$. Inscriptiones Graecae, Vol. 2 et 3, ed. tertia, Inscriptiones Atticae Euclidis anno posteriores; Pars 1, Leges et decreta. Fasc. 2, Leges et decreta annorum 352/1-322/1 (P.J. Rhodes) 234

LAMBERT (S.D) $E d$. Sociable Man: Essays on Ancient Greek Social Behaviour in Honour of Nick Fisher (M. Dimopoulou) 233

LANE FOX (R.J.) Ed. Brill's Companion to Ancient Macedon: Studies in the Archaeology and History of Macedon, 650 BC-300 AD (J. Engels) 242

LATTMANN (C.) Das Gleiche im Verschiedenen: Metapher des Sports und Lob des Siegers in Pindars Epinikien (P. Agocs) 166

LAURENCE (R.) and STRÖMBERG (A.) $E d s$. Families in the Greco-Roman World (V. Vuolanto) 254

LEGRAS (B.) $E d$. Transferts culturels et droits dans le monde grec et hellénistique: actes du colloque international (Reims, 14-17 mai 2008) (Z. Papakonstantinou) 247

LEIBOWITZ (D.) The Ironic Defense of Socrates: Plato's Apology (D. Engels) 285

LIAPIS (V.) A Commentary of the Rhesus Attributed to Euripides (D. Kokkini) 172

LULLI (L.) Narrare in Distici. L'elegia greca arcaica e classica di argomento storicomitico (M. Noussia-Fantuzzi) 165

MAC SWEENEY (N.) Community Identity and Archaeology. Dynamic Communities at Aphrodisias and Beycesultan (P. Thonemann) 257

MALKIN (I.) A Small Greek World: Networks in the Ancient Mediterranean (R. Osborne) 200

MARKANTONATOS (A.) and ZIMMERMANN (B.) $E d s$. Crisis on Stage: Tragedy and Comedy in Late Fifth-Century Athens (I. Ruffell) 182

MEYER (E.A.) Metics and the Athenian Phialai-Inscriptions: a Study in Athenian Epigraphy and Law (J.P. Sickinger) 205
MILLER (J.) Ed. Aristotle's Nicomachean Ethics: a Critical Guide (K.M. Nielsen) 290

MITSIS (P.) and TSAGALIS (C.) Eds. Allusion, Authority, and Truth: Critical Perspectives on Greek Poetic and Rhetorical Praxis (P. Agocs) 183

MODE (M.) and TURBACH (J.) Eds. Arms and Armour as Indicators of Cultural Transfer: the Steppes and the Ancient World from Hellenistic Times to the Early Middle Ages (A. Schofield) 237

MOORMANN (E.M.) Divine Interiors: Mural Paintings in Greek and Roman Sanctuaries (S. Pearson) 276

MOYER (I.S.) Egypt and the Limits of Hellenism (J. Skinner) 249

MUHS (B.P.) Receipts, Scribes, and Collectors in Early Ptolemaic Thebes (O. Taxes 2) (J. Tait) 250

MULLER-DUFEU (M.) "Créer du vivant»: sculpteurs et artistes dans l'Antiquité grecque (C. Marconi) 280

MUNTEANU-LaCOURSE (D.) Tragic Pathos: Pity and Fear in Greek Philosophy and Tragedy (S. Kiritsi) 177

MURRAY (W.M.) The Age of the Titans: the Rise and Fall of the Great Hellenistic Navies (B. Rankov) 238

NETZ (R.), NOEL (W.), TCHERNETSKA (N.) and WILSON (N.) Eds. The Archimedes Palimpsest (M. Sialaros) 292

NICHOLS (A.) Ctesias on India and Fragments of his Minor Works. Introduction, Translation and Commentary (D. Lenfant) 188

OLCESE (G.) Le anfore greco italiche di Ischia: archeologia e archeometria. Artigianato ed economia nel Golfo di Napoli (M.H. Crawford) 273

ORRELLS (D.), BHAMBRA (G.K.) and ROYNON (T.) Eds. African Athena: New Agendas (A.J.L. Blanshard) 232

PAJÓN LEYRA (I.) Entre ciencia y maravilla. El género literario della paradoxografía griega (A. Vergados) 195

PAPAZARKADAS (N.) Sacred and Public Land in Ancient Athens (M. Faraguna) 207

PETERSON (S.) Socrates and Philosophy in the Dialogues of Plato (M. Moes) 284

PETROPOULOS (J.C.B.) Kleos in a Minor Key: the Homeric Education of a Little Prince (M. Alden) 160

PIMOUGUET-PÉDARROS (I.) La Cité à l'épreuve de rois. Le siege de Rhodes par 
Démétrios Poliorcète (305-304 av. J.-C.) (L. Asmonti) 241

PLATT (V.) Facing the Gods: Epiphany and Representation in Graeco-Roman Art, Literature and Religion (C. Vout) 214

POWELL (A.) and HODKINSON (S.) $E d s$. Sparta: the Body Politic (E.G. Millender) 239 PROKOPOV (I) Die Silberprägung der Insel Thasos und die Tetradrachmen des 'thasischen Typs' vom 2.-1. Jahrhundert $v$. Chr (A. Meadows) 274

READY (J.L.) Character, Narrator, and Simile in the Iliad (P. Bassino) 159

REEVE (C.D.C.) Action, Contemplation and Happiness: an Essay on Aristotle (S. Baker) 291

REYDAMS-SCHILS (G.) Ed. Thinking Through Excerpts: Studies on Stobaeus (D.A. Christidis) 198

RICHARDSON (N.) Three Homeric Hymns: to Apollo, Hermes, and Aphrodite, Hymns 3, 4, and 5 (A. Kelly) 162

RIO (A.) $E d$. Law, Custom and Justice in Late Antiquity and the Early Middle Ages: Proceedings of the 2008 Byzantine Colloquium (J. Harries) 310

RIZZA (G.) Priniàs: la città arcaica sulla Patela: scavi condotti negli anni 1969-2000 (E. Santaniello) 266

ROBINSON (E.C.) Democracy Beyond Athens. Popular Government in the Greek Classical Age (S. Forsdyke) 229

ROSKAM (G.) and VAN DER STOCKT (L.) Eds. Virtues for the People. Aspects of Plutarchan Ethics (E. Kechagia-Ovseiko) 294

RUfFell (I.) Politics and Anti-realism in Athenian Old Comedy: the Art of the Impossible (M.J. Garcia Soler) 180

RUTHERFORD (R.B.) Greek Tragic Style: Form, Language and Interpretation (S.L. Schein) 173

SCHMITZ (T.) and WIATER (N.) Eds. The Struggle for Identity: Greeks and their Past in the First Century BCE (N. Giannakopoulos) 253

SENS (A.) Asclepiades of Samos: Epigrams and Fragments (R. Höschele) 193

SERGHIDOU (A.) Servitude tragique: esclaves et héros déchus dans la tragédie grecque (I. Torrance) 175

SERVI (K) The Acropolis. The Acropolis Museum (A. Baker) 281

SHARPLES (R.W.) Peripatetic Philosophy 200 $B C$ to AD 200: an Introduction and
Collection of Sources in Translation (M. Griffin) 303

SHIPLEY (G.) Ed. Pseudo-Scylax's Periplus: Text, Translation, and Commentary (K. Clarke) 227

SINIOSSOGLOU (N.) Radical Platonism in Byzantium: Illumination and Utopia in Gemistos Plethon (G. Zografidis) 306

SMITH (A.C.) Polis and Personification in Classical Athenian Art (S. Blundell) 271

SONNINO (M.) Euripidis Erechthei Quae Exstant, a cura di Maurizio Sonnino (M. Lipka) 171

SORABJI (R.) $E d$. Philoponus and the Rejection of Aristotelian Science (T. Popa) 299

SOURVINOU-INWOOD (C.) edited by R. Parker Athenian Myths and Festivals: Aglauros, Erechtheus, Plynteria, Panathenaia, Dionysia (E. Eidinow) 208

STAFFORD (E.) Herakles (T. Papadopoulou) 219

STRAMAGliA (A.) Phlegon Trallianus: Opuscula De rebus mirabilibus et De longaevis (K. Brodersen) 198

SUMMA (D.) Ed. Inscriptiones Graecae consilio et auctoritate Academiae Scientiarum Berolinensis et Brandenburgensis editae. Voluminis IX Partis I Editio altera. Fasciculus V. Inscriptiones Locridis orientalis (W. Mack) 236

TELL (H.) Plato's Counterfeit Sophists (F.V. Trivigno) 287

THALMANN (W.G.) Apollonius of Rhodes and the Spaces of Hellenism (T. Kenny) 192

THOMSEN (A.) Die Wirkung der Götter: Bilder mit Flügelfiguren auf griechischen Vasen des 6. und 5. Jahrhunderts v. Chr (A. Heinemann) 269

TRÜMPER (M.) Die 'Agora des Italiens' in Delos: Baugeschichte, Architektur, Ausstattung und Funktion einer späthellenistischen Porticus-Anlage (C.E. Barrett) 275

VAN BINSBERGEN (W.) $E d$. Black Athena Comes of Age (A.J.L. Blanshard) 232

VAN DOMMELEN (P.) and KNAPP (A.B.) $E d s$. Material Connections in the Ancient Mediterranean: Mobility, Materiality, and Mediterranean Identities (B. Legarra Herrero) 258

VAN NIJF (O.M.) and ALSTON (R.) Eds. with the assistance of C.G. Williamson Political Culture in the Greek City after the Classical Age (P.J. Rhodes) 231 
VERHEYLEN (J.) and TEULE (H.) Eds. Heretics and Heresies in the Ancient Church and in Eastern Christianity. Studies in Honour of Adelbert Davids (A. Louth) 308

VONDERSTEIN (M.) Der Zeuskult bei den Westgriechen (G. Biffis) 216

WALLACE (S.) Ancient Crete: from Successful Collapse to Democracy's Alternatives, Twelfth to Fifth Centuries BC (D.C. Haggis) 261

WOODRUFF (P.) The Ajax Dilemma: Justice, Fairness, and Rewards (G. Bruseker) 283
WOOLMeR (M.) Ancient Phoenicia: an Introduction (G. Sciortino) 202

WRIGHT (M.) The Comedian as Critic: Greek

Old Comedy and Poetics (I. Ruffell) 181

WRIGHT KNUST (J.) and VÁRHELYI (Z.) $E d s$. Ancient Mediterranean Sacrifice

(M.-Z. Petropoulou) 217

YASUMURA (N.) Challenges to the Power of Zeus in Early Greek Poetry (O. Thomas) 161

\section{BOOKS RECEIVED}

All books sent for review are deposited in our Joint Library of the Hellenic and Roman Societies, so that they are as widely available as is possible. Reviewers do not keep their review copies and are not remunerated in any other way. Full, cumulative monthly lists of accessions are to be found via our website, where the websites and marketing department contact details of the publishers who send us review copies are also to be found. The Hellenic Society gratefully acknowledges all such books received in the past year. 
The Society for the Promotion of Hellenic Studies was founded in 1879 to advance the study of Greek language, literature, history, art and archaeology in the ancient, Byzantine and modern periods. Membership is open to all and there is a reduced rate for students.

\section{MEMBERSHIP RATES}

Rates are as follows: full members $£ 47, £ 46$ for those who pay by direct debit; student associates $£ 25$; corporate members $£ 200$. Life membership is available at $£ 235$ to those over 65 years of age after five years' full membership. Institutional subscriptions are available from Cambridge University Press. Please consult the Society's website for further details (hellenicsociety.org.uk).

\section{PUBLICATIONS}

The Journal of Hellenic Studies and Archaeological Reports are published annually and sent to all members of the Society. Back numbers of The Journal of Hellenic Studies and Archaeological Reports may be ordered from the Society.

\section{THE JOINT LIBRARY}

The Society helps to maintain the Joint Library in conjunction with the Roman Society and the Institute of Classical Studies. Membership of the Hellenic Society allows the reader to borrow (within the UK) up to four books at a time, either in person or by post.

\section{LECTURES}

The Society arranges an annual lecture series in London, and helps to arrange other lectures in collaboration with the various local branches of the Classical Association: a programme of all these lectures is circulated in September to UK members and is posted on the website.

\section{GRANTS}

The Society aims to help those engaged in Hellenic studies at all levels, and to this end it makes grants of various kinds (further details and application forms are available from the website).

- Schools teaching Greek language, history or civilisation may apply for grants: generous donations from the A.G. Leventis Foundation have recently enabled the Society to increase the grants awarded, in number and size.

- Postgraduate students and other scholars engaged in specific areas of research may apply for grants from the Dover Fund.

- Institutions (typically, but not exclusively, universities) may apply for a grant from the Council of the Society, to fund academic conferences and other events.

\section{CONTRIBUTIONS TO THE JOURNAL}

Contributions should be anonymized and sent, preferably electronically, to the Editor r.w.brock@ leeds.ac.uk, with the subject 'JHS', or to Dr Roger Brock, Department of Classics, University of Leeds, Leeds LS2 9JT.

A style guide and further information on submission of copy and illustrations are available on the Society's website. Books for review should be addressed to the Librarian at the Society address. The Journal does not accept unsolicited book reviews.

Printed in the United Kingdom at Bell \& Bain Ltd, Glasgow 
Cambridge Journals online

For further information about this journal please go to the journal web site at

http://www.journals.cambridge.org/jhs UNIVERSITY PRESS 